\title{
Early to Mid-19th Century Occupation at the Dead Cow Site (41SM324), Smith County, Texas
}

Timothy K. Perttula

Heritage Research Center, Stephen F. Austin State University

Follow this and additional works at: https://scholarworks.sfasu.edu/ita

Part of the American Material Culture Commons, Archaeological Anthropology Commons, Environmental Studies Commons, Other American Studies Commons, Other Arts and Humanities Commons, Other History of Art, Architecture, and Archaeology Commons, and the United States History Commons

Tell us how this article helped you.

This Article is brought to you for free and open access by the Center for Regional Heritage Research at SFA ScholarWorks. It has been accepted for inclusion in Index of Texas Archaeology: Open Access Gray Literature from the Lone Star State by an authorized editor of SFA ScholarWorks. For more information, please contact cdsscholarworks@sfasu.edu. 


\section{Early to Mid-19th Century Occupation at the Dead Cow Site (41SM324), Smith County, Texas}

\section{Creative Commons License}

\section{(c) (1) \&}

This work is licensed under a Creative Commons Attribution-NonCommercial 4.0 International License 


\title{
Early to Mid-19th Century Occupation at the Dead Cow Site (41SM324), Smith County, Texas
}

\author{
Timothy K. Perttula
}

\section{INTRODUCTION}

The Dead Cow site is an early to mid-19th century archaeological site located within the northern part (Sabine River basin) of the proposed Republic of Texas 1836 Cherokee Indians land grant in East Texas (Figure 1), generally east of the downtown area of the modern city of Tyler. Cherokee Indians had moved into East Texas by the early 1820 s, and "most of the Cherokees cleared land and carved out farms in the uninhabited region directly north of Nacogdoches, on the upper branches of the Neches, Angelina, and Sabine rivers. By 1822 their population had grown to nearly three hundred" (Everett 1990:24).

To date, historic archaeological sites identified as being occupied by the Cherokee during their ca. 1820-1839 settlement of East Texas remain illusive, and to my knowledge no such sites have been documented to date in the region. This article considers, from an examination of the historic artifact assemblage found here, the possibility that the Dead Cow site is a Cherokee habitation site.

\section{BACKGROUND AND SITE SETTING}

Mark Walters recorded the site in January 2005 as a scatter of both prehistoric (lithic debris and a single ferruginous sandstone pitted stone) and 19th century artifacts covering a $30 \times 50 \mathrm{~m}$ area. The Dead Cow site was found after the land had been cleared for use as a pasture by the landowner; the area has also been mined for sand.

The site is on a lower ridge slope (390 feet amsl), with Cuthbert fine sandy loam sediments, overlooking the floodplain of Ray Creek at its junction with Five Mile Branch. Ray Creek is in turn a tributary of Harris Creek, one of the principal tributaries of the Sabine River in this part of East Texas.

\section{TH CENTURY ARTIFACTS}

The small collection of 19 th century artifacts from the surface of the Dead Cow site includes 29 stoneware and whiteware rim, body, and base sherds (Table 1) and four bottle glass sherds (Table 2). The most common artifacts in the assemblage are plain whiteware sherds, probably from plates, bowls, and cups.

Salt-glazed stoneware was one of the more commonly employed glazes in the manufacture of utilitarian stoneware (Greer 1981:180). The absence of salt-glazed stoneware sherds with a natural clay slipped interior surface from the Dead Cow site (but taking into account the small size of the artifact assemblage) suggests that this particular stoneware sherd came from a vessel that was made between the 1830s and ca. 1870 (Lebo 1987:140).

The other ceramics from the site are whitewares, and this type of ware was the predominant type of refincd carthenware made after the 1830s (Majewski and O'Brien 1987). About $60 \%$ of the whiteware sherds are from the undecorated portions of plates and cups. The earthy tones of the annular wares and mocha ware from the site-white, black, gray, and blue bands - suggest these sherds are from early (ca. 1840s) annular ware. The hand-painted sherds have fine-line polychrome floral motifs, including red dots and green petals as well as black branches, consistent with 1840-1860 hand-painted whitewares (Majewski and O'Brien 1987:157).

The one transfer-printed sherd from the Dead Cow site has a purple geometric pattern. The date range of production of this color of transfer-printed ceramics is 1814-1867 (Samford 2000:Table 5). However, the fact that this transfer-printed sherd is from a whiteware plate would seem to indicate that the occupation of the site could have ranged from ca. 1830-1867.

Both shell-edged plate rims are blue in color (see Table 1). With respect to the rim form of the Dead Cow site shell-edged ceramics, which is 


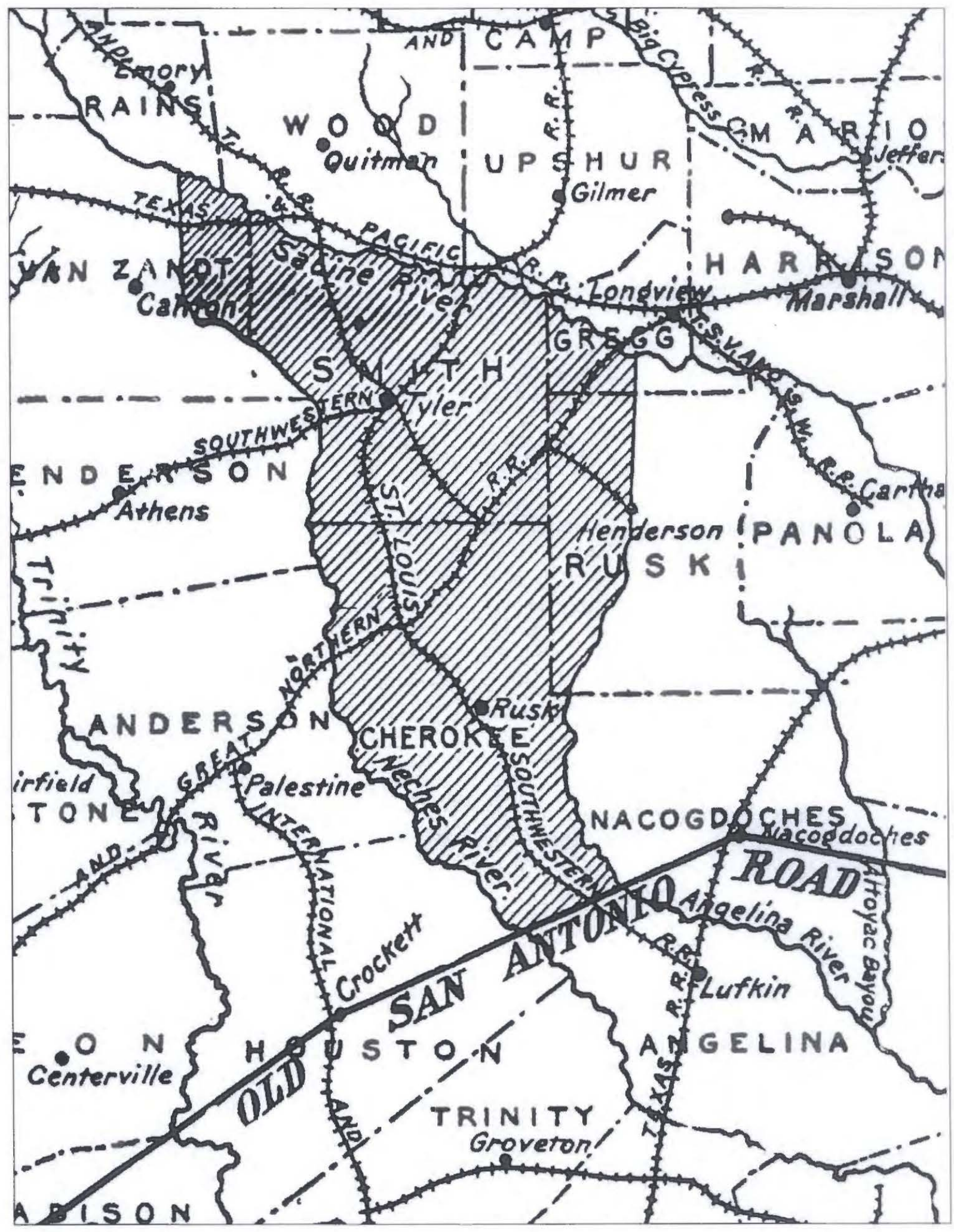

Figure 1. 1836 Cherokee land grant in East Texas. 
Table 1. Ceramic Sherds from the Dead Cow sitc.

\begin{tabular}{lc}
\hline Artifact category & No. \\
\hline Salt-glazed stoncware sherd & 1 \\
$\begin{array}{l}\text { Annular ware sherds, whiteware } \\
\text { Mocha ware sherd, whiteware }\end{array}$ & 3 \\
Hand-painted sherds, whiteware & 1 \\
Transfer-printed sherd, whiteware & 3 \\
$\begin{array}{l}\text { Blue shell-edged sherds with impressed } \\
\text { lines, non-scalloped lip. whiteware }\end{array}$ & 1 \\
Plain whiteware sherds & 2 \\
Plain whiteware rim sherd with impressed & 17 \\
lines, non-scalloped lip & 1 \\
\hline Totals & 29 \\
\hline
\end{tabular}

chronologically sensitive (cf. Hunter and Miller 1994, 2009), both have unscalloped rims and impressed lines (ca. 1830-1860). Hunter and Miller (2009:13) have more recently suggested that this form of rim on shell-edgcd plates was being made by the 1840 s, while the earlier symmetrical scalloped shell-edged ware continued to be made into the 1830s; this earlier form is absent in this small artifact sample.

The few pieces of bottle glass from the Dead Cow site are from hand-blown bottles of several different colors: aqua, colorless, and olive green (Table 2 ). These are likely from bottles that contained liquor (bcer and wine) or patent medicines. None of the bottle glass sherds have embossed lcttcring, suggesting they predate 1850 , when that technique began to be used (Newman 1970:74).

Table 2. Bottle Glass from the Dead Cow site.

\begin{tabular}{|c|c|}
\hline Artifact category & No. \\
\hline colorlcss bottle glass, patinated & 1 \\
\hline olive green bottle glass & 2 \\
\hline aqua bottle glass & 1 \\
\hline Totals & 4 \\
\hline
\end{tabular}

\section{CONCLUSIONS}

A small assortment of 19 th century artifacts, stoneware sherds, refined earthenware sherds, and bottle glass have becn recovered from the Dead Cow site in northern Smith County, and within the boundaries of the proposed 1836 Cherokee land grant. Could this be an archaeological site occupicd by the Cherokec Indians during their short stay (ca. 1820-1839) in East Texas?

On the basis of the kinds of artifacts found at the site, no determination of ethnic affiliation can be made. The same typcs of goods found at the site would have been available to both Cherokee (or other Native American groups in East Texas, including the Caddo) and Anglo-American settlers living in this same arca in the 1830s, and no archaeological or historical information is available that suggests that one group or the other had a particular preference for a specific kind of stoneware or refincd carthenware. The site also does not contain any historic Cherokee ceramics (of the late Qualla series, made until at least the late 19th century, see Riggs and Rodning 2002). The best available evidence that speaks to the possible cthnic affiliation of the site is the decorated refined earthenware. The preponderance of the evidence regarding the chronological age of these sherds would he consistent with a ca. 1840-1860 occupation, one that would have postdated the Cherokee occupation of East Texas. If the site postdated the Cherokee occupation, it is almost certainly the product of an Anglo-American settlement in the Sabine River basin.

Further archaeological investigations-including shovel testing and systematic metal detectingsecm warranted to gather a larger asscmblage of $191 \mathrm{~h}$ century arlifacts from controlled subsurface contexts. A larger assemblage of artifacts would likely contain more chronologically-specific specimens that could refine or refute the findings suggested here. Particular kinds of artifacts may also be found-such as glass beads, silver artifacts or evidence of its workmanship, mctal arrow points or other tools made from barrel or kettle scrap, or perhaps even sherds of Cherokee ceramics-that would lend much-needed support to the notion that the Dead Cow site was occupicd by the Cherokee Indian pcoplcs in the early part of the 19th century. 


\section{REFERENCES CITED}

Everett, D.

1990 The Texas Cherokee: A People Between Two Fires, 1819-1840. University of Oklahoma Press, Norman.

Greer, G. H.

1981 American Stoneware: The Art and Craft of Utilitarian Pottery. Schiffer Publishing Ltd., Exton, Pennsylvania.

Hunter, R. R. Jr. and G. L. Miller

1994 English Shell-edged Earthenware. Antiques CXLV (No. 3):432-443.

2009 Suitable for Framing: Decorated Shell-Edge Earthenware. Early American Life (August):8-19.

Lebo, S. A.

1987 Local Utilitarian Stonewares: A Diminishing Artifact Category. In Historic Buildings, Material Culture, and People of the Prairie Margin: Architecture, Artifacts, and Synthesis of Historic Archaeology, edited by D. H. Jurney and R. W. Moir, pp. 121-142. Volume V. Archaeology Research Program, Institute for the Study of Earth and Man, Southern Methodist University, Dallas.
Majewski. T. and M. J. O'Brien

1987 The Use and Misuse of Nineteenth-Century English and American Ceramics in Archacological Analysis. In Advances in Archaeological Method and Theory: Volume 11, edited by M. B. Schiffer, pp. 97-2099. Academic Press, Inc., New York.

Newman. T. S.

1970) A Dating Key for Post-Eighteenth Century Bottles. Historical Archaeology 4(1):70-75.

Riggs, B. H. and C. B. Rodning

2002 Cherokee Ceramic Traditions of Southwestern North Carolina, ca. A.D. 1400-2002: A Preface to "The Last of the Iroquois Potters." North Carolina Archaeology 51:34-67.

Samford, P. M.

2000 Response to a Market: Dating English Underglaze Transfer-Printed Wares. In Approaches to Material Culture Research for Historical Archaeologists, compiled by D. R. Brauner, pp. 56-85. 2nd Edition. The Society for Historical Archaeology. California, Pennsylvania. 